\title{
Understanding China's energy strategy and its sustained economic growth: present and future
}

\author{
Dan Shi
}

\author{
Correspondence: shidan01@163.com \\ Institute of Industrial Economics, \\ Chinese Academy of Social \\ Sciences, No.2 Yuetan Beixiaojie, \\ Beijing 100836, China
}

\begin{abstract}
Heavy investment on energy resources is one of the reasons for the rapid economic growth we have witnessed in China since 2000. Excessive energy consumption growth strengthens China's coal-dominated energy structure. Meanwhile, the supply of energy has been fully converted to net imports, weakening favorable factors for economic growth and increasing the risk of energy security. The nationalization level for the energy sector is much higher than for other industries. But even for stateowned enterprises, there is a huge gap in enterprise efficiency between different production processes. With a changing domestic and international energy market environment, China's energy industry should switch from the speed-oriented model in the past and adjust obsolete mechanisms and policies.we must first focus more on developing the service industry and optimizing the structure of the manufacturing industry.Second, the government must use fewer short-term economic interventions.Third, we should strengthen external regulations on energy monopolies. Fourth, we should attach great importance to energy security.

Keywords: Energy supply and demand; Energy security; Energy efficiency; Energy policy
\end{abstract}

The consumption and supply of energy have two major impacts on China's economy. On one hand, ongoing industrialization and urbanization in China demand increasing quantities of energy. A more efficient energy supply and a better energy infrastructure would boost the economy directly. On the other hand, energy production and consumption produce some negative externalities, such as pollution and greenhouse gases. If not controlled, these negative factors will eventually undermine economic sustainability.

China's energy consumption per GDP unit decreases as the economic structure evolves and technology advances. However, given China's $\mathrm{CO}_{2}$ reduction target for 2020 and the current state of both energy production and the environment, there will be less room for continued growth of China's energy supply. Sustained economic growth requires high energy efficiency and an optimized industrial structure for power generation. Since the breakout of the global financial crisis, China's economic growth has slowed down considerably, and Chinese demand for energy has fluctuated greatly. There are now more uncertainties than before in the development of China's power generation. Overcapacity and sagging profits are cropping up in many energy generation sectors. Even so, China continues to import more power, creating more concerns in the areas of energy conservation and energy security. In 2013, the Chinese government

(c) 2015 Shi. Open Access This article is distributed under the terms of the Creative Commons Attribution 4.0 International License (http://creativecommons.org/licenses/by/4.0/), which permits unrestricted use, distribution, and reproduction in any medium, provided you give appropriate credit to the original author(s) and the source, provide a link to the Creative Commons license, and indicate if changes were made. 
should enact another round of adjustments to the development of the power generation industry and to supply and demand for energy.

\section{Negative externalities of energy consumption are becoming more pressing, and industry restructuring is needed to cap consumption}

Resources, capital, and labor are the three key elements of economic growth. For the past three decades, China's economic growth has been the result of demographic dividends, high saving rates, and large inputs of energy resources. Favorable demographics lasted only through the 1990s. Thereafter, the demographic structure changed as growth of the working population slowed dramatically. In 2008, the contribution rate of labor to economic growth was more than three times less than in 1988 (Economy Research Project 2012). Nevertheless, China's economy continued to grow at even a higher rate. In addition to increasing contributions of capital inputs, energy inputs also accounted for a larger share of growth. From 1990 to 2010, Chinese standard coal consumption increased by 2260 million tons. To be more specific, it grew by 469 million tons from 1991 to 2000 and by 1794 million tons between 2001 and 2010. The growth rates for these two decades were almost the same: $10.43 \%$ for the first decade and $10.48 \%$ for the second. But overall energy consumption during the decade from 2001-2010 was 3.6 times higher than the decade from 1991-2000. It is safe to say that the high growth rate from 2001-2010 is attributable to increased resource inputs. In 2011, China's energy consumption per GDP unit was twice the world average, 2.4 times higher than in the USA, 3.7 times higher than in the European Union, 4.4 times higher than in Japan, and 1.1 times higher than in India. Those figures become 1.5 times, 2.1 times, 2.2 times, and 1.8 times if calculated based on Purchasing Power Parity (Wang 2012). In 2009, China's economy accounted for around $8.5 \%$ of the world economy, but for $45 \%$ of coal and $10 \%$ of oil and gas consumption.

China has only recently become a middle income country, and Chinese income per capita is still far behind that of developed countries. If China is to catch up with developed countries by simply consuming more energy, as it has for the past two decades, China will consume over $50 \%$ of the world's energy resources. Compared with the performance of developed countries at the same stage of industrialization, China's energy consumption fluctuates within a relatively low range. However, we should remember that the nature of world resource reserves at present makes it impossible for China to follow the same path of developed countries. China has to find a new road toward industrialization by consuming less energy and generating fewer emissions. In its eleventh five-year plan, the Chinese government put forward the target of reducing energy consumption by $20 \%$ per GDP unit. Despite this, rapid economic growth caused Chinese consumption of standard coal to grow by 889 million tons. The growth of China's coal consumption accounted for $91 \%$ of the world's total. With such a high consumption of coal, China has experienced many environmental problems in the past three decades, especially in areas with intensive energy production and consumption. In sharp contrast, environmental problems gradually emerged in as many as around 200 years in developed countries. Through analysis, scholars discovered that the growth of energy consumption in China is actually undermining economic growth (Liu et al. 2009). Both theoretical and empirical research show that there are increasing negative effects of energy consumption on economic development. Unless a proper response is made, this will adversely affect our goal of building a moderately prosperous society. 
A look at the relationship between the four five-year planning periods from 1990 to 2010 shows that the higher the demand for power, the higher the rate of coal production to energy consumption increases. From 1991 to 1995, standard coal consumption grew by 325 million tons, and coal output increased by 200 million tons of standard coal, accounting for $61.5 \%$ of total consumption. From 1996 to 2000, standard coal consumption grew by 144 million tons, and coal output increased by 16.92 million tons of standard coal, accounting for $11.7 \%$ of total consumption. From 2001 to 2005, standard coal consumption grew by 905 million tons, and coal output increased by 689 million tons of standard coal, accounting for $76.1 \%$ of total consumption. From 2006 to 2010, standard coal consumption grew by 889 million tons, and coal output increased by 593.54 million tons of standard coal, accounting for $66.2 \%$ of total consumption. Excessive energy inputs not only inflict damage on the environment, but also hinder the restructuring of the energy industry. Since 1990, economic development did not improve China's coal-dominated energy structure; in fact, the energy structure worsened. From 1990 to 2010, the energy production grew 1.86 times, and up to $79 \%$ of the total was produced by coal. The proportion of coal to total power generation increased from $74.2 \%$ in 1990 to $76.5 \%$ in 2010. Yet, according to the analysis of the Chinese Academy of Engineering, China's produces only ten million tons of coal per year. The problems of over-production and unsafe mining conditions only add to the negative externalities of China's power predicament. The burning of coal contributes $70 \%$ to total dust and smog emissions, $90 \%$ of $\mathrm{SO}_{2}$ emission, and $67 \%$ of NOx emissions.

By the end of the 11th 5-year plan, some regional administrations suspended power generation in order to reduce energy consumption per unit of GDP by $20 \%$. This disturbed the speed of production. Using administrative directives to restrict energy outputs ultimately goes against the goal of restricting the growth of power generation. The key to reducing negative externalities of energy consumption and increasing energy efficiency lies in upgrading the energy structure and the industrial structure. To control energy consumption during the 12th 5-year plan period, we should rely on economic instruments, such as price controls and taxes, and on encouraging upgrades to the industrial structure and promotion of new energy sources, rather than rashly taking administrative measures to curb energy consumption. In this way, we can achieve faster economic growth with fewer energy inputs.

\section{Overall energy self-sufficiency rate on the decline. We must solidify energy security}

China's per capita energy self-sufficiency is extremely lacking, with oil and gas selfsufficiency per capita being less than $10 \%$ of the world's average and coal less than $50 \%$ of the world's average. With limited resources and fast-growing consumption, China's ability to maintain energy self-sufficiency is on the wane. Since 1993, China's petroleum outputs have been around 200 million tons per year. Rapid growth of domestic petroleum demand has been satisfied largely through imports. In 2011, China's net oil imports, including crude oil, refined oil, liquefied petroleum gas (LPG), and other petroleum products, totaled 272.86 million tons, an increase of $7.6 \%$. The Chinese dependence rate on imported petroleum jumped from $58.7 \%$ in 2010 to $59.8 \%$ in 2011. Chinese domestic natural gas consumption came to 129 billion cubic meters, a year-on-year increase of $20.6 \%$. For natural gas, including liquefied natural gas and natural gas imported through pipelines, our import volume expanded by up to $89 \%$, accounting for about $33.3 \%$ of total consumption, up by $15 \%$ over 2010 . China is the world's largest producer of coal, contributing over $40 \%$ 
of global coal output. Yet, it must be stressed that China has been a net importer of coal since 2009. In 2011, China's crude coal output was 3.52 billion tons, with a record increase of 280 million tons over the previous year. Its net import of coal was 168 million tons, up by a record $15.2 \%$ year-on-year, making China the biggest coal importer worldwide.

In 2012, China's economic growth slowed down. Overcapacity in coal production is now becoming a problem. Coal prices are down, but still higher than international prices. As a consequence, the volume of imported coal continues to increase, aggravating overcapacity in the coalmining industry. Current overcapacity is the result of excessive exploitation of coal resources. China has been mining coal for only 80 years, 120 years less than the world average of 200 years. As geological conditions are complex, coal mining in China is relatively difficult. A number of mines are very deep. The average depth of a Chinese mine has reached $600 \mathrm{~m}$, with some exceeding $1000 \mathrm{~m}$. In comparison, over two thirds of the USA's 1.1 million tons of coal output are mined from open pits. The Chinese coal mining industry will gradually internalize the external costs of coal development. Mid- to long-term development costs, especially marginal costs (notably for coal mines in Eastern and Central China), will likely be reduced to the current cost levels of mines in Europe. Cost comparisons demonstrate that China will continue to rely on imported coal in the long run.

According to Chinese empirical analysis, energy exports can boost the economy to a certain extent, but energy imports do not significantly stimulate the economy (Liu J. An Empirical study on China's energy trade and economic growth from http://www.paper.eud.cn). China's being a net importer undermines its strength while at the same time increases the risk of interruptions to the energy supply. Currently, China's self-sufficiency rate for petroleum is merely $44.08 \%$, and our strategic petroleum reserves are good for only 35 days, far less than the security reserve of 90 days requested by the IEA. Ninety-one percent of China's imported crude oil is imported by sea, but there is insufficient security for seaborne imports into China. It is estimated that by 2030, China's dependence rate on imported petroleum will reach 70 \%. From 2020 onwards, energy security will likely be a serious issue in China.

\section{State-owned energy influence on the rise, but efficiency still low}

The energy industry is much more nationalized than other industries in China. Largescale state-owned energy companies are becoming increasingly important parts of China's economy. Statistics gathered from 41 industries demonstrate that in 2011, the total output value of coal, petroleum, petrochemicals, and electricity accounted for $14.6 \%$ of overall industrial output, and accounted for $10.5 \%$ of total employment, down by 2 percentage points from 2005. Yet, in state-owned enterprises, the industrial output value of the above four energy industries accounted for up to $43.1 \%$ of the national total, nearly 2 percentage points higher than in 2005. For electricity, state-owned enterprises control over $95 \%$ of the nation's power generation capacity. In petrol, the three large-scale petrol companies produce over $97 \%$ of crude oil and over $80 \%$ of processed petroleum nationwide. Around $50 \%$ of petrol stations are owned by the three large state-owned enterprises. For years, Sinopec Group, China National Petroleum Corporation, and the State Grid Corporation of China have been the top three companies a top China's "Fortune 500" list. The China Southern Power Grid Company, the Group of China National Offshore Oil Corporation, and China National Chemical Group rank at 14th, 16th, and 17th, respectively. The 
Shenhua Group Co., Ltd occupies the top rank in its industry. Five power groups are also on the list.

The proportion of state-owned enterprises in the energy industry is decreasing, but it is still much larger than in other domestic industries. Compared to 2005, the proportion of state-owned enterprises in coal, oil, and electricity are down by 7 percentage points, 23 percentage points, and 13 percentage points, respectively. Among those, the coal industry is the least nationalized at $9.5 \%$. Yet, it is still 5 percentage points higher than the national average. In terms of output value, nationalized coal companies accounted for $56.5 \%$ of the total for above-scale companies, down by 12 percentage points from 2005. The same indicator in petroleum is $94.7 \%$, up by 3.7 percentage points from 2005, and $92.3 \%$ in electricity, up by 3.3 percentage points. Although there are fewer state-owned oil and electricity enterprises, their scale of production is up, and they occupy more market share. The key to increasing the level of nationalization in the energy industry lies in increasing the productivity of state-owned energy enterprises.

Nevertheless, there is a profit gap between state-owned companies in different processing stages. Despite higher levels of labor productivity, the petroleum refining industry and the coal-fired power generation industry have significantly lower profit rates than their upstream industries, such as the oil drilling industry and the coal mining industry (see Tables 1 and 2). The coal-fired power generation industry seems to be suffering from further sagging profits.

\section{New energy growing rapidly, but the development model needs adjustment}

China's new energy industry is once again an economic growth point. During the 11th 5-year plan period from 2001 to 2005, the technology output value of China's new energy industry was the highest in the world. According to a report published by the World Wide Fund for Nature (WWF) on May 9, 2011, China's clean energy technology output value Zhas been increasing by $77 \%$ year-on-year since 2008, for a total amount of over US\$64 billion, the highest in the world. Of the industries included in that value, wind power, turbine manufacturing, and photovoltaic manufacturing exhibited the fastest growth. Before 2000, turbines manufactured in China accounted for less than $10 \%$ of the domestic market. That percentage grew to over $30 \%$ in 2005 and further to over $85 \%$ in 2009. Over the same period, Chinese new energy companies have expanded

Table 1 Labor productivity and per capita profit for energy companies, private and state-owned. Unit: 10 thousand yuan/person

\begin{tabular}{|c|c|c|c|c|c|c|c|c|}
\hline & \multicolumn{2}{|l|}{ Coal } & \multicolumn{2}{|l|}{ Petrol } & \multicolumn{2}{|c|}{ Petrochemical } & \multicolumn{2}{|l|}{ Electricity } \\
\hline & Productivity & $\begin{array}{l}\text { Profit per } \\
\text { capita }\end{array}$ & Productivity & $\begin{array}{l}\text { Profit per } \\
\text { capita }\end{array}$ & Productivity & $\begin{array}{l}\text { Profit per } \\
\text { capita }\end{array}$ & Productivity & $\begin{array}{l}\text { Profit per } \\
\text { capita }\end{array}$ \\
\hline $\begin{array}{l}\text { Industry } \\
\text { average }\end{array}$ & 41.94 & 6.54 & 93.51 & 28.54 & 317.30 & 13.25 & 147.12 & 7.14 \\
\hline $\begin{array}{l}\text { State-owned } \\
\text { enterprises }\end{array}$ & 36.05 & 5.69 & 92.06 & 28.39 & 476.07 & 16.85 & 154.20 & 7.08 \\
\hline $\begin{array}{l}\text { Foreign- } \\
\text { invested } \\
\text { companies }\end{array}$ & 181.61 & 39.48 & 1250.11 & 687.59 & 446.90 & 24.22 & 218.82 & 22.56 \\
\hline $\begin{array}{l}\text { Private } \\
\text { companies }\end{array}$ & 50.07 & 6.75 & 74.78 & 13.73 & 149.86 & 8.72 & 64.31 & 5.10 \\
\hline
\end{tabular}

Source: calculated on statistics by the author 
Table 2 State-owned company profit rate in different industries. Unit: \%

\begin{tabular}{lrrr}
\hline & 2006 & 2010 & 2010 on 2006 \\
\hline Oil drilling & 47.3 & 30.8 & -16.5 \\
Oil refinery & -3.6 & 3.5 & 7.1 \\
Coal mining & 8.3 & 15.8 & 7.5 \\
Coal electricity & 7.6 & 4.6 & -3.0 \\
\hline
\end{tabular}

Source: calculated by the author

quickly. Sinovel Wind Group's machine manufacturing volume was the third largest in the world, occupying $9.5 \%$ of the world market in 2009. Gold Wind ranked 5th with a global market share of $7.4 \%$. Dongqi Energy Corporation ranked 7th with $6.9 \%$ of the global market share for new machines. China's photovoltaic industry has also enjoyed a productivity boom in recent years. In 2007, China's PV equipment exports reached US $\$ 3.49$ billion. In 2011, that volume was 10 times higher than in 2007, at a total of US\$35.82 billion. Photovoltaic cell and module production volume in China is the largest in the world with a global market share of over $50 \%$. Suntech and Yingli Group are two examples of large Chinese private enterprises listed in foreign markets with global operations. The rapid development of the new energy industry has played a part in boosting China's economy. In areas where the new energy industry is being extensively developed, output value, profit and avenue contribution, and export value were once as high as 10, 15, and $25 \%$, respectively (Li and Zhang 2009).

As China's PV and wind energy exports have grown rapidly, Chinese companies have become the victims of protectionism abroad. The USA launched an anti-dumping and anti-subsidy investigation into turbine equipment and PV products imported from China, causing huge losses to Chinese companies. The verdict against China has greatly hindered Chinese PV equipment exports to the USA. Following in the footsteps of the USA, the German Solar Energy Association planned to raise an anti-dumping case in 27 EU countries against China. Such protectionism practices suffocate China's rapid growth in the new energy industry. China's solar photovoltaic product exports dropped over the period from January to June 2012, after rapid growth for six consecutive years. The industry's exports are now valued at US\$12.894 billion, down YoY by $31.49 \%$. Leading enterprises such as Suntech, Jiangxi Saiwei, and Baoding Yingli endured huge export losses, while some others saw their share prices plummet in American stock markets. Those companies which performed the best in the past suffered the greatest losses.

Such cases reveal the fragility of China's photovoltaic industry. Its rapid growth has been driven mainly by external demand, which adds to the industry's uncertainty. The industry should switch its focus from manufacturing for foreign markets to manufacturing for domestic markets.

\section{Chinese energy supply and demand relationships in 2013 and policy priorities}

In the foreseeable future, China's demand for energy will keep growing along with the economy. It is worth mentioning from past experience that fluctuations in supply and demand are influenced greatly by economic growth. Among the energy industries, coal and electricity have shorter cycles and greater fluctuations. In 2012, China's growth slowed down due to long-term and cyclical factors. In the short-term, the European debt 
crisis negatively affected Chinese exports. In the long-term, China, as the world's second largest economy, can no longer rely on exports as much as it used to. China's demographics are changing, and now the country is beginning to suffer from labor shortages. As the global economy is shifting toward greener technology and less energy consumption, China is transitioning its development model from an energy-intensive one to an energy-conserving one. The factors discussed above may lower the potential growth down from its current double-digit stature. As such, supply and demand in energy will not be the same as before. Coal plants under construction will be finished between 2013 and 2015, further worsening the overcapacity situation. Coal-fired plant operation hours will remain in mid to low levels. It will be hard for electricity generated by new energy sources to make it onto the grid, due to decreased demand, limited peaking capability, and system bottlenecks. To adapt to changing internal and external markets, we must reform ineffective systems and policies and dump the intensive, scale-oriented model of the past.

To achieve this, we must first focus more on developing the service industry and optimizing the structure of the manufacturing industry. Developing the service industry is the key to breaking energy bottlenecks and reducing environmental destruction. Generally, energy consumption in the service industry is much lower than in manufacturing. Conditions are mature for China to quicken its development of the service industry. To begin with, with a university/college graduate population of 5.7 million entering the workforce every year, China's is quickly accumulating human resources. Second, R\&D investments are growing rapidly. China overtook Japan in 2010 to become the second largest investor in R\&D worldwide. Third, China has the largest scale of manufacturing in the world, which means there is a huge potential market for producer services. Last but not least, China's income per capita has exceeded US $\$ 5000$, which means that service expenditures will grow rapidly.

To develop the service industry, the Chinese government should no longer view speed of growth as its top priority, but instead should strengthen support for the service industry by providing better policies for public finances, taxes, finance, land transfers, and pricing. We should create a better system for fostering innovations, a better standards system, a better intellectual property system, and a better statistics system in order to provide a better environment for the service industry. In developed nations, when the service industry overtakes manufacturing, the economic growth rates are lower. However, the economy becomes more stable and provides better living conditions for the citizens. As manufacturing is the basis for the service industry, China should maintain the third industrial revolution and quicken the development of hi-tech and high-end equipment manufacturing in order to be more competitive on the world stage with a stronger, not bigger, manufacturing industry.

Second, the government must use fewer short-term economic interventions. China's rapid economic growth stems partially from strong government interventions, but frequent and over-forceful interventions have also caused problems. Short-term interventions are always characterized by excessiveness and single-mindedness, leading to deviations from long-term goals and slowdowns to industrial restructuring. Countermeasures and support policies intended to counteract protectionism in international trade should be made within a proper scale so as to allow time and space for the market to balance supply and demand and to allow for industrial restructuring. 
In order to fundamentally resolve frequently occurring shortages and surpluses in energy sources, we should institute energy price formation mechanisms, increased market access, and exit mechanisms. Currently, there is no transparent pricing mechanism for energy products except for coal. The government still sets the prices for grid feed-in tariffs, electricity, refined oil, and natural gas, although the latter two tend to fluctuate with prices in the global market. Energy prices do not affect consumption, investments, and resources unless they reflect supply and demand, resource availability, and a particular activity's environmental impact. Besides, without market access and exit mechanisms, the Chinese market is not able to adjust either supply or production capacity.

Third, we should strengthen external regulations on energy monopolies. Energy companies always employ vertical integration in their management. As energy production grows more concentrated than before, problems have arisen such as inadequate benefits for employees and high costs of public services. To protect their own interest, large-scale companies influence the government by their disproportionate market shares and hinder industry restructuring. In China, we should let the government and the market play their own due roles by keeping the government and enterprises separate and deepening the reforms of enterprise ownership. On top of routine social regulation, an independent and comprehensive regulatory body should be established to strengthen the auditing and monitoring of energy costs. We should eliminate policies, laws, regulations, and red tape that favor state-owned monopolies. The government should eliminate discrimination toward non-state-owned enterprises, lift limitations to market access in all industries, and channel private investment properly via policy measures.

Fourth, we should attach great importance to energy security. As we Chinese enjoy continued economic growth, we must remain aware that we are importing more energy resources. Our relationships with other countries are bound to change. More tension is bound to appear in China's relations with major powers and with neighboring countries. Energy security is a long-term concern. We should begin to strengthen regional energy corporations in foreign policies, speed up law making, strengthen the petroleum and other energy resources reserve system and capacity, and accelerate the development of new energy industry.

Competing interests

The author declares that she has no competing interests.

Authors' information

Shi Dan is a research fellow and Deputy Director of National Academy of Economic Strategy, CASS. Her main research areas are the energy economy and industrial policies.

Received: 21 September 2012 Accepted: 11 October 2012

Published online: 11 December 2015

References

Economy Research Project A Strategic Study on China's Economic Growth for 2020, by Development and Reform Commission, Review of Economic Research, 2012 43B-3 Page 6

Li H, Zhang F. On New Energy Industry Future Development in Hebei Province-Starting from China's Electricity Valley Baoding in Economic Forum. 2009.

Liu J. An Empirical study on China's energy trade and economic growth fromhttp://www.doc88.com/p8909045722193.html

Liu. C, Guo. X, Jian. Y: Study on How Energy Consumption Affects China's Economic Growth-A Comparison Between Linear and Non-Linear Regressionin Industry Economic Research, 2009 Issue 1

Wang Q. China's Energy Efficiency Analysis in China Energy. 2012. Issue 8. 